\title{
Homerocentony jako najbardziej skrajna próba hellenizacji chrześcijaństwa
}

\author{
Homerocentos as the Most Extreme Attempt to Hellenize Christianity
}

\author{
MAREK GILSKI \\ Uniwersytet Jana Pawła II w Krakowie \\ marek.gilski@upjp2.edu.pl, ORCID: 0000-0003-4588-2038
}

\begin{abstract}
Streszczenie: Artykuł prezentuje i ocenia jedną z prób hellenizacji chrześcijaństwa. Chodzi o Homerocentony, powstające w kręgach chrześcijańskich od IV wieku utwory, przekazujące przesłanie Ewangelii niemal wyłącznie za pomocą słownictwa lliady i Odysei. Tekst zawiera omówienie techniki tworzenia tych dzieł, ich treść, formę i teologię. Analiza Homerocentonów prowadzi do następujących wniosków: a) nie da się zrozumieć i właściwie zinterpretować chrześcijaństwa bez znajomości poematów homeryckich; b) Ewangelia jest tylko nową interpretacją lliady i Odysei; c) chrześcijaństwo nie wnosi nowych treści, a jedynie porządkuje to, co dostępne w kulturze.
\end{abstract}

Słowa kluczowe: Homerocentony, hellenizacja, chrześcijaństwo

Abstract: This article presents and evaluates one of the attempts to Hellenize Christianity. It concerns the Homerocentos, works written in Christian circles from the 4th century onwards, which convey the message of the Gospel almost exclusively using the vocabulary of the lliad and the Odyssey. The text includes a discussion of the technique of creating these works, their content, form, and theology. The analysis of Homerocentos leads to the following conclusions: a) it is impossible to understand and properly interpret Christianity without the knowledge of Homeric poems; b) the Gospel is only a new interpretation of the lliad and the Odyssey; c) Christianity does not bring new content, but only organizes what is available in culture.

Keywords: Homerocentos, Hellenization, Christianity

Zakończenie prześladowań chrześcijaństwa przez Konstantyna Wielkiego, a zwłaszcza próba ograniczenia działalności edukacyjnej chrześcijan w czasach Juliana Apostaty, doprowadziły do pojawienia się nowej formy przekazu Ewangelii ${ }^{1}$. Chodzi o tzw. centony, utwory będące wyrazem kompilacji innych dzieł, ale dokonanej w taki sposób, aby stworzyć nowe dzieło. Nie jest to przypadkowe połączenie fragmentów z różnych pozycji ani tym bardziej antologia na jakiś temat, lecz dzieło treściowo nowe, posiadające nowy sens, nowy przekaz, całkowicie nowe przesłanie ${ }^{2}$.

Green, „Proba’s Cento”, 551-563; Prieto Domínguez, De alieno nostrum, 67.

2 Gilski, Mariologia centonów, 11. 
Sam termin „centon”, wywodzący się z języka greckiego (kentron), jest spolszczoną formą łacińskiego pojęcia (cento). Etymologicznie znaczenie terminu nawiązuje do idei zszywania, łączenia różnych elementów ${ }^{3}$.

Centony były znane na długo przed chrześcijaństwem ${ }^{4}$. Miały charakter zarówno religijny, jak i świecki. Techniką centonu posługiwali się w II wieku gnostycy, o czym wspomina Ireneusz z Lyonu w Adversus haereses ${ }^{5}$. Ojcowie Kościoła niejednokrotnie krytycznie oceniali centony (Ireneusz z Lyonu, Hieronim, Izydor z Sewilli) ${ }^{6}$ ze względu na metodę ich tworzenia. Były one przecież efektem wyrywania zdań, sformułowań z ich właściwego kontekstu, aby je umieścić w nowym kontekście, zmieniając tym samym ich sens. Ale już u apologetów wczesnochrześcijańskich (Minucjusz Felix) można spotkać krótkie centony, co świadczy, że krytyka tej formy literackiej nie miała charakteru powszechnego ${ }^{7}$. We wstępie do jednej z wersji centonów pojawia się wzmianka o biskupie Patrycjuszu jako ich twórcy. Chodzi o blizzej nieznaną postać z IV wieku ${ }^{8}$ Także chrześcijanki (żyjąca w IV wieku Proba) ${ }^{9}$ próbowały na podstawie techniki centonu ukazać treści zawarte na kartach Starego i Nowego Testamentu, wykorzystując $\mathrm{w}$ tym celu dzieła Wergiliusza ${ }^{10}$. Autorzy centonów w większości albo w ogóle nie są znani, nawet $\mathrm{z}$ imienia, albo niewiele o nich wiadomo ${ }^{11}$.

Tak więc można mówić o dwóch nurtach w podejściu do centonów: jedni odnosili się do nich bardzo krytycznie, podczas gdy inni nie mieli obaw przed ich komponowaniem.

Centony napisane w języku łacińskim Dekret Gelazego zalicza do literatury apokryficznej ${ }^{12}$. Różnią się one jednak znacząco od apokryfów. Autorstwo żadnego ze

3 Usher, Homeric Stitchings, 1-2; Prieto Domínguez, De alieno nostrum, 19-30; Sandnes, The Gospel 'According to Homer and Virgil', 107. Zob. Prieto Domínguez, „Historia del centón griego”, 217-232.

4 O pierwszych centonach greckich można mówić już w kontekście komedii Arystofanesa. Zob. Prieto Domínguez, De alieno nostrum, 62.

5 Wilken, „The Homeric Cento”, 25-33.

6 Gilski, Mariologia centonów, 12-14.

7 Minucjusz Felix w dziele Oktawiusz $(19,2)$ skomponował krótki, bo składający sie zaledwie z sześciu wersów centon z Eneidy i Georgik Wergiliusza. Sandnes, The Gospel 'According to Homer and Virgil', 125.

8 Cesarzowa Eudocja w połowie V wieku dokonała korekt i - jak sama zaznacza - poprawiła wersję centonów autorstwa biskupa Patrycjusza. Usher, Homeric Stitchings, 19.

9 Według tradycji miało chodzić o Faltonię Betitię Probę, babkę Proby znanej z listów św. Augustyna. Sandnes, The Gospel 'According to Homer and Virgil', 141.

10 Chodzi o składający się z 694 wersetów centon z dzieł Wergiliusza. Pierwsza jego połowa opowiada o stworzeniu świata, potopie i Noem, podczas gdy druga koncentruje się na treściach nowotestamentowych. Gilski, Mariologia centonów, 183-184. Tłumaczenie angielskie i komentarz do centonu: Clark Hatch, The Golden Bough.

11 Niewiele wiadomo o takich autorach centonów jak Optimus czy Kosma Jerozolimski. Patricius - Eudocie - Optimus - Côme de Jérusalem, Centons Homérique (Homerocentra). Dwunastowieczny manuskrypt centonów przywołuje postać bliżej nieznanego Simplicjusza. Holum, Theodosian Empresses, 220. Do naszych czasów dotrwały także centony, których autorzy nie są znani nawet z imienia. Chodzi np. o liczący 111 wersetów utwór De Verbi incarnatione. Ziółkowski - Putnam, The Virgilian Tradition, 481.

12 Pojawia się tam stwierdzenie: „Centonem de Christo virgilianis conpaginatum versibus apocryphum”. Baron - Pietras, Dokumenty synodów od 431 do 504 roku, 322. 
znanych centonów nie było przypisywane apostołom. Także sposób ich tworzenia był inny. Niejednokrotnie wykorzystywały one bowiem grę słów, co sprawiało, że mogły nasuwać negatywne skojarzenia. Twórcy centonów cytowali bowiem często fragmenty charakteryzujące postacie o wątpliwej moralności i manipulując kontekstem, używali ich do opisu Jezusa ${ }^{13}$ czy Maryi ${ }^{14}$. W centonach nie znajdziemy nagromadzenia cudownych zdarzeń. Przypominają więc one raczej parafrazę aniżeli klasyczne apokryfy.

Popularność centonów w świecie chrześcijańskim każe jednak bardziej szczegółowo przyjrzeć się zarówno ich treści, jak i roli, którą odgrywały. Próbowano tworzyć centony nie tylko z dzieł napisanych w języku greckim, ale i z utworów łacińskich. Różni autorzy starali się przekazać Ewangelię zarówno językiem Homera, Ajschylosa, Eurypidesa, Lykofrona, jak i Wergiliusza ${ }^{15}$. Jednak próby oparte na poematach Homera trzeba uznać za najbardziej udane ze względu na długość utworów i ich zakres treściowy ${ }^{16}$. Dlatego przedmiotem analiz staną się właśnie centony homeryckie, nazywane także Homerocentonami. Pojawiły się one w IV i V wieku i natychmiast zyskały sporą popularność, o czym świadczą różne ich wersje i spora liczba manuskryptów. Kolejne wieki (V-XII) to czas tworzenia nowych Homerocentonów i modyfikowania już znanych ich wersji ${ }^{17}$.

Celem artykułu jest odpowiedź na pytanie, w jakiej mierze Homerocentony są wyrazem próby hellenizacji chrześcijaństwa. Jest to, jak się wydaje, próba najbardziej skrajna w tym sensie, że postrzega chrześcijaństwo jako element kultury greckiej ${ }^{18}$.

W przypadku Homerocentonów należałoby prawdopodobnie zawęzić pojęcie hellenizacji do terminu „homeryzacja”. Utwory te bowiem łączą przesłanie Ewangelii nie tyle z całą kulturą helleńską, co z jej najbardziej wybitnymi i jednymi z najstarszych dzieł. Chociaż Iliada i Odyseja niosą w swojej szacie literackiej, pod postacią mitu, sporo treści o charakterze filozoficznym ${ }^{19}$, to jednak greccy filozofowie (np.

13 Wydarzenia z życia Jezusa Chrystusa są prezentowane na podstawie cytatów z poematów Homera, które odnoszą się do mężczyzn (Odys, Hektor, Agamemnon, Telemach, Achilles, Bellerofont, Nestor) i kobiet (Penelopa, Nauzykaa), bogów (Zeus, Hefajstos, Apollon, Posejdon, Ares) i bogiń (Hera, Atena, Afrodyta, Kalipso, Kirke). Nie brak więc postaci, które negatywnie zapisały się na kartach Iliady czy Odysei. Drzyżdżyk, Chrystologia w perspektywie Mitu Trojańskiego, 155-191.

14 Do charakterystyki Maryi autor centonów wykorzystuje fragmenty Eneidy Wergiliusza, odnoszące się do Dydony, która popełniła samobójstwo, a także teksty Eurypidesa, charakteryzujące Medeę, która zabiła swoje dzieci. Gilski, Mariologia centonów, 215-216.

15 Gilski, Mariologia centonów, 18.

16 W przypadku centonów wergiliańskich mamy do czynienia z utworami czterokrotnie krótszymi i bardzo zdawkowo oddającymi przesłanie Ewangelii. Zob. McGill, „Virgil, Christianity, and the Cento Probae”, 173-174.

17 Gilski, Mariologia centonów, 20.

18 Przykładem hellenizacji na nieco mniejszą skalę są różnego rodzaju apokryficzne akta apostołów. Zob. MacDonald, Christianizing Homer.

19 Gilski, Koncepcja wzroku w poematach homeryckich, 10-11. 
Platon) bardzo krytycznie odnosili się do nich ${ }^{20}$. A zatem same poematy Homera nie były euforycznie przyjmowane przez wszystkich przedstawicieli świata helleńskiego.

Zainteresowanie Homerocentonami w ostatnim czasie wzrosło zwłaszcza za sprawą ich krytycznych wydańn ${ }^{21}$, tłumaczeń i komentarzy ${ }^{22}$. Zarówno pozycje książkowe, jak i artykuły koncentrują się przede wszystkim na perspektywie lingwistycznej, a rzadziej na teologicznej. Na gruncie polskim badaniami nad teologią centonów zajmują się głównie Dariusz Piaseckii ${ }^{23}$ i Szymon Drzyżdżyk ${ }^{24}$. Z literatury obcojęzycznej do najbardziej znaczących badaczy należą tłumacze i autorzy krytycznych wydań (André-Louis Rey, Rocco Schembra) ${ }^{25}$. Trudno natomiast wskazać - czy to w literaturze polskiej, czy to światowej - pozycje o charakterze bardziej ogólnym, które traktowałyby o konsekwencjach płynących z ich tworzenia. Obecny artykuł stara się wypełnić tę lukę.

Analizy zostaną przedstawione w następującym porządku. Po ukazaniu techniki autora Homerocentonów, prezentującej Ewangelię jako pozostającą w ścisłym związku z poematami Homera, zostanie zaprezentowana ich treść (odcięcie od starotestamentowych korzeni), aspekt formalny (pozbawienie perspektywy historycznej i topograficznej), a na koniec ich niedomagania chrystologiczne.

\section{Chrześcijaństwo jako jedna z wersji poematów Homera}

Badania nad Homerocentonami pokazują, że poza bardzo nielicznymi wyjątkami (pojedyncze wersety) są one w całości skonstruowane $\mathrm{z}$ wersetów zaczerpniętych z Iliady i Odysei. Nie zawierają niemal żadnych innych dodatków ${ }^{26}$. Wyjątkiem są niektóre nazwy chrześcijańskie (imiona) wprowadzone jako produkt całkowicie

20 Lamberton, „Introduction”, X-XI.

21 Patricius - Eudocie - Optimus Côme de Jérusalem, Centons Homérique (Homerocentra); Schembra, Homerocentones. Wydanie Schembry zawiera pięć manuskryptów uporządkowanych od najdłuższego do najkrótszego: „Conscirptio prima”, „Conscriptio secunda”, „Conscriptio alfa”, „Conscriptio beta”, „Conscriptio gamma”. Źródłowe teksty będą przytaczane za tym wydaniem, z podaniem nazwy manuskryptu i numeru wersetu.

22 Schembra, La prima redazione; Schembra, La secunda redazione.

23 Piasecki, „Hermeneutyka Centonu Homeryckiego”; Piasecki, „Pochodzenie nazw własnych w Centonach Homeryckich”; Piasecki, Centony Homeryckie; Piasecki, „Centony Homeryckie”; Piasecki, „Eucharystia u Homera?".

24 Drzyżdżyk, „Demonologia Homerocentonów”; Drzyżdżyk, Chrystologia w perspektywie Mitu Trojańskiego; Drzyżdżyk, „Homerocentos and the Ontology of Christ”; Drzyżdżyk, „Protologia Homerocentonów”.

25 Szczegółowy opis stanu badań nad centonami (nie tylko homeryckimi), zob. Patricius - Eudocie - Optimus Côme de Jérusalem, Centons Homérique (Homerocentra) (Narecki, 427-449). 
sztuczny. Najdłuższe z tych dzieł zawierają pięćdziesiąt perykop biblijnych, niemal wyłącznie z Ewangelii ${ }^{27}$.

Niezależnie od zamierzeń autorów tego typu dzieł - najprawdopodobniej chodziło o ukazanie przesłania ewangelicznego w języku i poetyce pochodzących z najbardziej cenionych w kulturze greckiej utworów - rodziły one szereg pytań oraz wątpliwości i budziły uzasadniony opór niektórych ojców Kościoła. Ich krytyczne uwagi miały jednak charakter zdawkowy i nie wydobywały wszystkich konsekwencji płynących z tego typu zabiegów literackich. W dużej mierze były podyktowane faktem, że pierwszymi twórcami chrześcijańskich Homerocentonów byli walentynianie ${ }^{28}$.

Ta krytyka była ostra, aczkolwiek nie pogłębiona z tej racji, że wielu ojców Kościoła widziało w poematach Homera szansę ewangelizacyjną. Chodziło zwłaszcza o perypetie Odyseusza, które stały się niemal paradygmatem dla mówienia o historii człowieka na ziemi i o jego powrocie do niebieskiej ojczyzny, do domu Ojca ${ }^{29}$. Faktem jest, że tworzeniu takich utworów sprzyjały podobieństwa między Biblią a poematami Homera ${ }^{30}$.

Warto jednak w tym miejscu ukazać konsekwencje płynące z tworzenia Homerocentonów. Skoro na podstawie Iliady i Odysei można przekazać najważniejsze przesłanie Ewangelii, to prowadzi to do bardzo istotnej konkluzji: Ewangelia jest pewną wersją poematów Homera. To, co ona przynosi, nie jest żadną nowością, lecz tylko nowym uporządkowaniem - zgodnie z techniką centonu - znanych z literatury greckiej treści. Homerocentony niosą zatem ze sobą przesłanie o ścisłym powiązaniu Ewangelii i kultury greckiej. Chrześcijaństwo to nowa forma kultury greckiej, wcześniej ukryta, a obecnie wydobyta.

Związana z Homerocentonami hellenizacja chrześcijaństwa miałaby polegać nie tyle na wprowadzaniu do Ewangelii i do teologii nowych pojęć, nowych konotacji terminów, nowych znaczeń, nowych sposobów myślenia, lecz na czymś o wiele głębszym i istotnym - na pokazaniu, że chrześcijaństwo w samych swoich źródłach i korzeniach jest greckie.

Sama technika centonu wydaje się być tworem kultury greckiej ${ }^{31}$. A zatem nawet narzędzie pozwalające na wydobycie z poematów Homera ich ukrytej treści ma pochodzenie greckie. Nie można, jak się wydaje, bardziej zhellenizować chrześcijaństwa, aniżeli stwierdzić, że wszystko w nim jest od początku do końca greckie, nie tylko pod względem treści, ale i narzędzi do ich interpretacji.

\footnotetext{
27 Omówienie układu i treści jednej z wersji Homerocentonów, zob. Piasecki, Centony Homeryckie, 13-16.

28 Sandnes, The Gospel 'According to Homer and Virgil', 128-139.

29 Szerokie opracowanie tego zagadnienia, zob. Rahner, Griechische Mythen in christlicher Deutung.

30 Zob. West, Wschodnie oblicze Helikonu, 443-567; MacDonald, The Homeric Epics; MacDonald, Does the New Testament Imitate Homer?

31 Zob. Prieto Domínguez, De alieno nostrum, 62.
} 


\section{Odcięcie od starotestamentowych korzeni}

Niektóre wersje Homerocentonów, jakkolwiek nieliczne, zawierają opis grzechu rajskiego $^{32}$. I to jest ich jedyny związek ze Starym Testamentem. Brak jest w nich jednak jakichkolwiek nawiązań do innych wydarzeń. Nie znajdziemy w nich ani proroctw mesjańskich, ani elementów mądrościowych, ani przywołania takich postaci jak Abraham czy Dawid. Jest to fakt zdumiewający z tej racji, że przecież Septuaginta zawiera szereg fragmentów, które są dowodem na rozumienie Starego Testamentu w kluczu mądrości starożytnych Greków. Przykładem mogą być choćby wzmianki o syrenach ${ }^{33}$. Przekład Starego Testamentu na język grecki wiązał się więc z pewnymi adaptacjami. Jednak nawet te idee nie znalazły miejsca w Homerocentonach. Jest to, jak się wydaje, działanie zamierzone, które znajduje swoje dopełnienie w treści analizowanych utworów. Homerocentony koncentrują się na czynach Jezusa, w niewielkim jedynie stopniu przywołując Jego nauczanie. Nie prezentują przypowieści. Tym samym wpisują się w główny nurt kultury greckiej - koncentrację na wzroku ${ }^{34}$. Kategoria słowa, dominująca w Starym Testamencie, niemal nie dochodzi w nich do głosu. Homerocentony najwięcej miejsca poświęcają cudom Jezusa ${ }^{35}$.

Mamy więc do czynienia $\mathrm{z}$ sytuacją absolutnie wyjątkową. Homerocentony odcinają się od pewnych starotestamentowych nawiązań do kultury greckiej po to, aby stać się jej całkowitym wykwitem. Tezy ojców Kościoła o „teorii kradzieży” - jakoby wszystko, co dobre w kulturze greckiej, było efektem czerpania z Mojżesza - tracą tym samym sens i podstawę ${ }^{36}$. To nie Objawienie przekazane w Starym Testamencie jest źródłem mądrości dla Greków, lecz odwrotnie. Mądrość starożytnych ma swoje źródło w kulturze greckiej.

Chrześcijaństwo w perspektywie Homerocentonów nie szuka w innych kulturach i religiach ziaren prawdy (semina veritatis), lecz ono samo wydaje się zawierać jedynie pewne jej elementy.

32 Chodzi o drugą co do długości wersję Homerocentonów. W niej scena przedstawiająca grzech rajski pojawia się po opisie narodzenia Jezusa. „Conscriptio secunda”, 181-210. Wydaje się mieć rację Drzyżdżyk („Protologia Homerocentonów”, 124), gdy twierdzi: „Struktura Homerocentonów, w których scena zwiastowania i narodzenia Syna Bożego poprzedza opis grzechu rajskiego, jest dowodem na to, że kluczową ich ideą nie jest grzech, lecz plan zbawienia ludzkości. Akcent nie pada zatem na pierwotną winę, lecz na miłosierdzie Boga, który obdarza ludzi swoją łaską". Omówienie tego fragmentu, zob. Sandnes, The Gospel 'According to Homer and Virgil', 189-192.

33 Sześciokrotnie w Septuagincie pojawiają się syreny jako tłumaczenie hebrajskich słów oznaczających szakala lub samicę strusia. Zob. Drzyżdżyk, „Demonologia Homerocentonów”, 90.

34 Zob. Gilski, Koncepcja wzroku w poematach homeryckich.

35 Piasecki, Centony Homeryckie, 15; Drzyżdżyk, Chrystologia w perspektywie Mitu Trojańskiego, 233.

36 Zob. Droge, Homer or Moses?, 1-2. 


\section{Rezygnacja z kontekstu historycznego i topograficznego}

Jedną z zasadniczych cech analizowanych utworów jest niewielka liczba nazw własnych $^{37}$, przez co ginie zarówno perspektywa topograficzna, jak i historyczna. Autorowi chodziło o ukazanie treści biblijnych na podstawie poematów Homera, dlatego też unikał posługiwania się tymi fragmentami Iliady i Odysei, które zawierały nazwy nieobecne na kartach Nowego Testamentu.

W Homerocentonach pojawia się sporo zaimków, co sprawia, że wiele fragmentów może być rozumianych w różnych sensach i odnoszonych do różnych postaci. Mamy więc do czynienia $z$ jakimiś formami uogólnienia. Pewne fragmenty mogą być paradygmatyczne i odnosić się do chrześcijaństwa albo do innej religii czy kultury. W tej perspektywie przesłanie Ewangelii staje się jedną z wielu możliwości odczytania ukrytego sensu poematów Homera.

Tak rozumiana hellenizacja chrześcijaństwa sytuuje je w kręgu nurtów gnostyckich. Jego przesłanie mogą bowiem odczytać jedynie ci, którzy zostali wtajemniczeni w kulturę grecką. Dla innych jest ono niedostępne. Jest to poniekąd odwrócenie rozwiązania problemu znanego z kart Dziejów Apostolskich, dotyczącego związku chrześcijaństwa z judaizmem. Homerocentony dają inne rozstrzygnięcie aniżeli apostołowie zebrani na tzw. „soborze jerozolimskim” (Dz 15). Według analizowanych utworów trzeba zapoznać się z kulturą grecką, aby móc właściwie zrozumieć przesłanie Ewangelii. Chrześcijaństwo i kultura grecka pozostają ze sobą ściśle złączone.

Doskonałą ilustracją tej kwestii wydaje się być przykład podany przez Ireneusza z Lyonu, który porównuje technikę tworzenia centonów do wykonywania mozaiki. $\mathrm{Z}$ tych samych elementów można jednak ułożyć różne kształty. Ireneusz, charakteryzując literackie zabiegi walentynian, napisał tak:

To tak jakby miało się autentyczny obraz jakiegoś króla, przedstawiony starannie przez zdolnego artystę, (mozaikę) złożoną z drogich kamieni. I oto przychodzi ktoś i burzy zarys ludzkiej postaci, rozrzuca kamienie i inaczej je układa, i tworzy z nich postać psa albo lisa, i w dodatku jeszcze w artystycznie gorszym wydaniu, a potem mówi i wyjaśnia, że jest to właśnie wspomniany piękny obraz króla, który zestawił zdolny artysta, co więcej, wskazuje na poszczególne kamienie, które pięknie zestawił był pierwszy artysta dla obrazu króla, a teraz nieudanie zostały przeniesione przez drugiego twórcę do obrazu psa. Ale przez ten obraz z mozaikowych kamieni zwodzi niedoświadczonych ludzi, którzy nie mają żadnego pojęcia o postaci królewskiej, i wmawia im, że ta śmierdząca postać lisa jest pięknym obrazem króla. W taki sam sposób postępują, gdy baśnie starych bab (por. 1 Tm 4,7) prze-

37 W niektórych manuskryptach znajdują się nieliczne nazwy typowe dla poematów Homera: „Achajowie”, „Kronida”, „Tytani”, „Olimp”. „Conscriptio secunda”, 12-13, 38, 73, 134. Opis sceny zwiastowania nie posiada ani jednej nazwy własnej, która określałaby miejsce lub osoby. „Conscriptio prima”, 206-274. 
rabiają, a następnie zestawiają je z mowami i powiedzeniami oraz przypowieściami, chcą uzgodnić Słowa Boże ze swoimi baśniami ${ }^{38}$.

Ireneusz miał na myśli krótki centon, który opisywał zstąpienie Jezusa do otchłani, odwołując się do przykładu Heraklesa udającego się do Hadesa po psa Cerbera.

Biskup Lyonu porównuje centon do mozaiki, podczas gdy Drzyżdżyk do puzzlii" Zarówno jedna analogia (mozaika), jak i druga (puzzle) ukazują perspektywy, które te utwory otwierają. Chodzi o niemal nieograniczone możliwości układania nowych dzieł. Faktem jest, i to trzeba uczciwie przyznać, że Homerocentony prezentują przesłanie o życzliwości Boga i Jego planie zbawienia ludzi, odwołując się do tekstów nacechowanych politeizmem i niemoralnością bogów.

\section{Konsekwencje w obszarze chrystologii}

Poematy Homera należały do podstawowego kanonu lektur w starożytności, zarówno w świecie greckim, jak i rzymskim ${ }^{40}$. To na Iliadzie i Odysei uczono się czytać i pisać. Z poematów Homera tworzono nawet coś w rodzaju katechizmów w postaci pytań i odpowiedzi ${ }^{41}$. Wielu starożytnych znało te teksty na pamięć. Dlatego ma rację Ronald F. Hock, gdy twierdzi, że czytanie Homera było elementem greckiej tożsamości ${ }^{42}$.

Na tej podstawie stało się możliwe odczytanie treści ewangelicznych w Homerocentonach. Znajomość poematów Homera sprawiała jednak, że sens Ewangelii był odczytywany w kontekście Iliady i Odysei. A to rzutowało na myślenie o Bogu i ludziach. O ile niektóre ich fragmenty można odczytać trynitarnie, to jednak chrystologia wyłaniająca się z kart Homerocentonów, jak zauważa Drzyżdżyk, jest z jednej strony antymodalistyczna, a z drugiej - apolinarystyczna ${ }^{43}$. Ponieważ brak jest na kartach poematów Homera idei śmierci Boga (możliwa jest sytuacja odwrotna, to znaczy unieśmiertelnienia człowieka), to chrystologia z konieczności zbliża się bądź to do zniekształconego monofizytyzmu (herosi), bądź to do nestorianizmu. Śmierć może dosięgnąć jedynie herosa lub człowieka. W przypadku Homerocentonów,

\footnotetext{
38 Irenaeus, Adversus haereses I, 8, 1 (Myszor, 48).

39 Drzyżdżyk, Chrystologia w perspektywie Mitu Trojańskiego, 231-232.

40 Sandnes, The Challenge of Homer, 19.

41 Hock, „Homer in Greco-Roman Education”, 65.

42 Trudno przecenić wpływ Homera na ówczesną edukację, skoro nazwy własne z poematów były pierwszymi słowami, których uczyli się uczniowie, wersety z Homera były pierwszymi zdaniami, które czytali, fragmenty z Iliady i Odysei były pierwszymi tekstami, które opanowywali na pamięć i interpretowali, wydarzenia i tematy z poematów były pierwszymi, do których się odwoływali w swoich ćwiczeniach, a metafory homeryckie były przez nich często używane do ozdabiania swoich wypowiedzi i do autoprezentacji. Szerzej na ten temat, zob. Hock, „Homer in Greco-Roman Education”, 56-77.

Drzyżdżyk, Chrystologia w perspektywie Mitu Trojańskiego, 232-233.
} 
a zatem układanki z różnych tekstów, pozostaje jeszcze możliwość połączenia dwóch różnych kontekstów - śmierci w kontekście ludzkim, a życia w kontekście boskim. Ale wtedy mamy do czynienia $\mathrm{z}$ dwiema różnymi osobami, co zbliża chrystologię do poglądów nestoriańskich. Homerocentony gubią novum Wcielenia i to, obok braku pneumatologii, jest - z punktu widzenia treści - ich największym mankamentem ${ }^{44}$.

Niektóre partie Homerocentonów musiały budzić u ich czytelników pewien niesmak. Dotyczyło to zwłaszcza chrystologii. Przedstawienie Jezusa - który na krzyżu nie mógł poruszyć rękami ani nogami - za pomocą fragmentu Odysei, traktującego o cudzołożnym Aresie złapanym in flagranti dzięki niewidzialnej pułapce Hefajstosa $^{45}$, nasuwało negatywne skojarzenia. I Jezus, i Hefajstos nie mogli się poruszyć. Ale różne były przyczyny tego stanu rzeczy ${ }^{46}$. Centonista wykorzystał także - do ukazania idei namaszczenia Jezusa Duchem Świętym w czasie chrztu w Jordanie fragment Iliady na temat namaszczenia Hery. Bogini korzysta z różnych zabiegów kosmetycznych (w tym także namaszczeń) po to, aby oszukać i uwieść Zeusa ${ }^{47}$. Ryzykowne wydaje się również wykorzystanie przez autora centonów sztuki magicznej Kirke do ukazania mocy Eucharystii ${ }^{48}$. W ten sposób kluczowe sceny z Ewangelii zostały przedstawione na podstawie fragmentów budzących śmieszność i kojarzących się z magią i zachowaniami nieetycznymi.

\section{Podsumowanie}

Analiza Homerocentonów prowadzi do ambiwalentnych ocen. Z jednej strony wydaje się mieć rację Drzyżdżyk, gdy twierdzi, że są one oznaką siły teologii, „która potrafi włączyć w swoją refleksję treści nie tylko nie mające nic wspólnego z Ewangelią, lecz nawet $\mathrm{w}$ jakiejś mierze $\mathrm{z}$ nią sprzeczne" ${ }^{\mathrm{M} 9}$, a $\mathrm{z}$ drugiej utwory te niosą ukryte przesłanie o chrześcijaństwie jako religii zawartej w sposób ukryty na kartach najważniejszych dzieł literatury greckiej. Chrześcijanie pierwszych wieków również nie byli zgodni w ocenie Homerocentonów. Widzieli w nich duże możliwości ewangelizowania, zwłaszcza w czasie prześladowań, w sposób ukryty, a z drugiej obawiali się pozbawiania chrześcijaństwa jego wyjątkowości i sprowadzania go jedynie do wariantu greckiej mitologii.

\footnotetext{
44 Gilski, Mariologia centonów, 216.

45 „Conscirptio prima”, 1892.

46 Wydarzenie opisane w Odysei wywołało śmiech u obserwatorów. Gilski, Koncepcja wzroku w poematach homeryckich, 170-172.

47 „Consciptio secunda”, 385.

48 „Conscirptio prima”, 1465.

49 Drzyżdżyk, Chrystologia w perspektywie Mitu Trojańskiego, 236.
} 
Homerocentony, chociaż posiadają pewne walory, które mogły sprzyjać dziełu ewangelizacji, to jednak z kilku względów wydają się być najbardziej skrajną formą hellenizacji chrześcijaństwa: po pierwsze, z racji ich redukcjonizmu (odcięcie od Starego Testamentu, systematyczne pomijanie nauczania Jezusa, a koncentracja na Jego czynach); po drugie, z racji braków w sferze dogmatyki (nieobecność pneumatologii, gubienie novum wcielenia Syna Bożego); po trzecie, z racji czerpania wzorców z zachowań nieetycznych; po czwarte, z racji metody ich tworzenia, opartej na manipulacji tekstem; po piąte, $\mathrm{z}$ racji wyłaniającego się po ich lekturze wrażenia, że novum Ewangelii ogranicza się do innego usystematyzowania idei obecnych na kartach Homera.

Konsekwencją hellenizacji chrześcijaństwa w każdej postaci, czy to Homerocentonów, czy też innej, jest koncentracja na wzroku. A to oznacza odcięcie od ważnego sposobu przekazu wiary, która przecież rodzi się ze słuchania (Rz 10,17).

\section{Bibliografia}

Baron, A. - Pietras, H. (red.), Dokumenty synodów od 431 do 504 roku (Kraków: WAM 2011).

Clark, E.A. - Hatch, D.F., The Golden Bough. The Oaken Cross. The Virgilian Cento of Faltonia Betitia Proba (Chico, CA: Scholars Press 1981).

Droge, A.J., Homer or Moses? Early Christian Interpretations of the History of Culture (Tübingen: Mohr Siebeck 1989).

Drzyżdżyk, S., „Demonologia Homerocentonów”, Bielsko-Żywieckie Studia Teologiczne 17 (2016) 89-98.

Drzyżdżyk, S., ,Homerocentos and the Ontology of Christ”, Analecta Cracoviensia 50 (2018) 11-22.

Drzyżzżyk, S., „Protologia Homerocentonów - w poszukiwaniu natury pierwotnej winy”, Studia Gnesniensia 33 (2019) 115-126.

Drzyżdżyk, S., Chrystologia w perspektywie Mitu Trojańskiego (Kraków: Scriptum 2017).

Gilski, M., Koncepcja wzroku w poematach homeryckich (Kraków: Scriptum 2010).

Gilski, M., Mariologia centonów (Kraków: Scriptum 2015).

Green, R.P.H., „Proba’s Cento: Its Date, Purpose, and Reception”, Classical Quarterly 45/2 (1995) 551-563.

Hock, R.F., „Homer in Greco-Roman Education”, Mimesis and Intertextuality in Antiquity and Christianity (red. D.R. MacDonald) (Harrisburg, PA: Trinity Press 2001) 56-77.

Holum, K.G., Theodosian Empresses. Women and Imperial Dominion in Late Antiquity (Berkeley, CA: University of California Press 1982).

Irenaeus, Adversus haereses, tł. pol. W. Myszor: Ireneusz z Lyonu i gnostycy. Zdemaskowanie i odparcie fałszywej gnozy. Tłumaczenie: Adversus haereses. Ksiegga I i II (Katowice: Księgarnia św. Jacka 2016).

Lamberton, R., „Introduction”, Homer's Ancient Readers. The Hermeneutics of Greek Epic's Earliest Exegetes (red. R. Lamberton - J.J. Keaney) (Princeton, NJ: Princeton University Press 1992) VII-XXIV. 
MacDonald, D.R., Christianizing Homer. The Odyssey, Plato, and The Acts of Andrew (New York - Oxford: Oxford University Press 1994).

MacDonald, D.R., Does the New Testament Imitate Homer? Four Cases from the Acts of Apostles (New Haven, CT - London: Yale University Press 2003).

MacDonald, D.R., The Homeric Epics and the Gospel of Mark (New Haven, CT - London: Yale University Press 2000).

McGill, S., „Virgil, Christianity, and the Cento Probae”, Texts and Culture in Late Antiquity. Inheritance, Authority, and Change (red. J.H.D. Scourfield) (Swansea: Classical Press of Wales 2007) 173-193.

Patricius - Eudocie - Optimus Côme de Jérusalem, Centons Homérique (Homerocentra) (introduction, texte critique, traduction, notes et index A.-L. Rey) (Sources chrétiennes 437, Paris: Cerf 1998), tł. pol. D. Piasecki: Centony Homeryckie (Kraków: Scriptum 2017).

Piasecki, D., „Centony Homeryckie. Wczesnochrześcijańskie parafrazy literackie”, Sosnowieckie Studia Teologiczne 12 (2015) 275-285.

Piasecki, D., „Eucharystia u Homera?”, Vox Patrum 69 (2018) 561-572.

Piasecki, D., „Hermeneutyka Centonu Homeryckiego - studium przypadku”, Littera Antiqua 2 (2011) 121-136.

Piasecki, D., „Pochodzenie nazw własnych w Centonach Homeryckich”, Littera Antiqua 5 (2012) 101-114.

Piasecki, D., Centony Homeryckie. Spotkanie tradycji pogańskiej z chrześcijańską (Kraków: Scriptum 2014).

Prieto Domínguez, O., De Alieno Nostrum. El Centón profano en el mundo griego (Acta Salmanticensia. Estudios filológicos 328; Salamanca: Ediciones Universidad de Salamanca 2010).

Prieto Domínguez, O., „Historia del centón griego”, Cuadernos de filología clásica. Estudios griegos e indoeuropeos 19 (2009) 217-232.

Rahner, H., Griechische Mythen in christlicher Deutung (Basel: Herder 1984).

Sandnes, K.O., The Challenge of Homer. School, Pagan Poets and Early Christianity (London: Clark 2009).

Sandnes, K.O., The Gospel 'According to Homer and Virgil'. Cento and Canon (Leiden - Boston, MA: Brill 2011).

Schembra, R. (red.), Homerocentones (Turnhout: Brepols 2007).

Schembra, R., La prima redazione dei centoni omerici. Traduzione e commento (Alessandria: Edizioni dell'Orso 2006).

Schembra, R., La seconda redazione dei centoni omerici. Traduzione e commento (Alessandria: Edizioni dell'Orso 2007).

Usher, M.D., Homeric Stitchings. The Homeric Centos of the Empress Eudocia (Lanham, MD: Rowman \& Littlefield 1998).

West, M.L., Wschodnie oblicze Helikonu. Pierwiastki zachodnioazjatyckie w greckiej poezji i micie (Kraków: Homini 2008).

Wilken, R.L., „The Homeric Cento in Irenaeus 'Adversus haereses' I, 9, 4”, Vigiliae Christianae 21 (1967) 25-33.

Ziółkowski, J.M. - Putnam, M.C.J., The Virgilian Tradition. The First Fifteen Hundred Years (New Haven, CT - London: Yale University Press 2008). 
